\title{
The Modification of Beef Cattle's Feces and Urine as the Source of Organic Fertilizer to Increase Sweet Corn's Productivity (Zea mays saccharata sturt)
}

\author{
Sri Arnita Abu Tani ${ }^{1, *}$ Zulfa Elymaizar ${ }^{2}$, Endri Musnandar $^{3}$ \\ 1, 2, ${ }^{3}$ Faculty Of Animal Husbandry Jambi University-Indonesia \\ ${ }^{*}$ Corresponding author. Email: sriarnita.1963@gmail.com
}

\begin{abstract}
Feces and urine from beef cattle are not yet fully optimized by farmers. If there is a modification process with the feces and urine, it can be a source of organic fertilizer. Other than helping farmers with their fertilizer needs and supply, it will also reducing the environmental pollution. The purpose of this research is to understand feces and urine modification produced by beef cattle to increase the productivity of sweet corn's plant. Randomized Block Design (RBD) 7 treatments and 5 repetition groups were being used in this research. P0 (without fertilizer), P1(1 NPK),P2(3/4NPK),P3(3/4NPK+ 1/2Organic),P4 (3/4 NPK+ 1 organic), P5 (3/4NPK+ 11/2 Organic),P6 (1 NPK + 1 organic). Variable being observed consisted of: growth power (\%), fruit weight (g), sweet corn production (ton ha-1), and sweet corn waste production (ton ha-1). Data obtained were being analyzed by an analysis of variance and Duncan's test. The results showed that the growing power of $\mathrm{P} 3, \mathrm{P} 4, \mathrm{P} 5$, and $\mathrm{P} 6$ applications were higher $(\mathrm{P}<0.05)$ than $\mathrm{P} 2$ and $\mathrm{P} 1$, the fruit weights of $\mathrm{P} 5$ applications were greater $(\mathrm{P}<0.05)$ than $\mathrm{P}$ 3, $\mathrm{P} 2$, $\mathrm{P} 1$, and $\mathrm{P}$, and fruit weight from applications $\mathrm{P} 1$, $\mathrm{P} 2, \mathrm{P} 3$, and $\mathrm{P} 4$ were not significantly different $(\mathrm{P}<0.05)$. Likewise, with the application of $\mathrm{P} 4, \mathrm{P} 5$, and $\mathrm{P} 6$, the result of fruit weights was not significantly different $(\mathrm{P}<0.05)$. The production of sweet corn from P3, P4, P5, P6 applications was higher $(\mathrm{P}<0.05)$ than applications $\mathrm{P} 0, \mathrm{P} 1$, and $\mathrm{P} 2$. The highest production of sweet corn waste was obtained from the application of $\mathrm{P} 4$ and $\mathrm{P} 5$ and the lowest was in the application of $\mathrm{P} 0(\mathrm{P}<0.05)$, between $\mathrm{P} 4$ and $\mathrm{P} 5$ the production of sweet corn waste was not significantly different ( $\mathrm{P}>0.05)$. The productivity of sweet corn (Zea mays Saccharata Sturt) through the application of modified beef cattle feces and urine with a combination $\left(3 / 4 \mathrm{NPK}+1 \frac{1 / 2}{2}\right.$ Organic) on sweet corn (Zea mays Saccharata Sturt) land increased as seen from the growing power, fruit weight, Sweet Corn production (Zea mays L. saccarata sturt.), and sweet corn waste (Zea mays saccharata sturt ).
\end{abstract}

Keywords: Productivity, Organic Fertilizer, Modification, Sweet Corn.

\section{INTRODUCTION}

In general, farmers are still implementing the traditional farming system. The use of chemical fertilizers (inorganic) is quite high, even they are dependent on subsidized fertilizers whose availability is not continuous in reality. The availability of subsidized fertilizers is not always in line with the farmers' needs, due to that reason, the productivity of the farming is not optimal. The use of chemical fertilizers without subsidies will also increase production costs. Besides, excessive use of chemical fertilizers (inorganic) will cause an increase in greenhouse gas emissions such as $\mathrm{N}_{2} \mathrm{O}, \mathrm{CH}_{4}$, and $\mathrm{CO}_{2}$, thus potentially increasing global warming
Along with the farmers' need for fertilizers, the availability of solid and liquid beef cattle waste in the form of feces and urine at the farmer level is quite high, but it has not been used optimally and usually allowed to pile up around the stables. Farmers who have not optimally utilized the solid and liquid waste of beef cattle will also have the potential to increase greenhouse gas emissions in the form of $\mathrm{CH}_{4}$ and $\mathrm{CO}_{2}$. These emissions are coming from livestock, resulted from digestion and livestock management activities. Of all livestock commodities, cattle are the producer of methane gas $\left(\mathrm{CH}_{4}\right)$ more than other ruminants. While in fact, methane gas $\left(\mathrm{CH}_{4}\right)$ becomes the second-largest greenhouse gas (GHG) which causes global warming [1] 
To overcome this, there is a need to utilize beef cattle waste in the form of feces and urine to be used as a source of composting material for organic fertilizers through the use of Trichoderma Harzianum Spp as a bio-activator. Usually, beef cattle feces processed with Trichoderma Harzianum Spp will produce organic fertilizer in the form of Trichokompost. To increase the potential of the farming area, it is necessary to utilize the waste produced from the area to increase the nutrient content of the Trichocompost produced, one of the wastes that can be utilized is banana stem waste which is added as one of the constituent materials of Trichokompos, so that fecesbased Trichokompos from cattle and banana stem waste can be produced (Trichokompos FLBP). Laboratory test results on the quality of the FLBP Trichocompost with 29.15\% C-organic, C/ N 28, 38.02 moisture content, macronutrients; $(\mathrm{N}+\mathrm{P} 2 \mathrm{O} 5+\mathrm{K} 20) 4.54 \%, \mathrm{pH} 8$ (Balitanah, 2019), these results are in accordance with the PERMENTAN 01/2019 standard. The urine that is not used by farmers will also be processed into biourine through fermentation technology using the Trichoderma Spp bioactivator based on banana stem waste. Biourine added with microorganisms will produce growth regulators, namely gliberin and cytokinins [2], beef cattle urine contains nitrogen levels $36.90-37.31 \%$, phosphate 16.5 - $16.8 \mathrm{ppm}$, and calcium $0.67-1.27 \%$ ( Zein, 2011)[3]. From a physical point of view, cow urine has more odor than cow feces [4]

Based on the potential for solid and liquid beef cattle waste in the form of feces and urine, it can be modified into a source of organic fertilizer to be applied to various plants in an effort to increase crop production. In this study, modification of cow feces and urine in the form of Trichokpompos FLB and Beef Biuorine will be tested in various combinations with inorganic fertilizers on sweet corn (Zea mays saccharata sturt) so that it is hoped that the best combination can be implemented to farmers to increase sweet corn production (Zea mays saccharata sturt) and its waste production, which can supply the farmers with the need for cattle feed.

\section{MATERIALS AND METHODS}

\subsection{Land Preparation}

The sweet corn plantations prepared in this study were 0,1 ha, processed using a hand tractor, which was made into 35 pillows. The distance from one pillow to the next pillow was $100 \mathrm{~cm}$ with a height of $\pm 20 \mathrm{~cm}$ and each pillow had two rows of plants, designed in a Randomized Block Design (RBD) 7 treatments and 5 replications, placement of treatments, and the test was carried out randomly.

\subsection{Planting}

Corn seeds used in Bonanza F1 research. Corn seeds were planted with a depth of $3 \mathrm{~cm}$. Each pillow had two rows of plants with a spacing of $50 \mathrm{~cm} \times 40 \mathrm{~cm}$. One corn seed was planted in each hole. If the seeds do not grow or die, they will be replaced with other corn seeds that are prepared at the reserve yard.

\subsection{Fertilization}

\subsubsection{Inorganic Fertilizer}

Inorganic fertilizers used in the study are urea $(300$ $\mathrm{kg}^{-1}$ ha dose), KCL (100 kg/ha dose), TSP (200 kg/ha dose), and dolomite (2000 kg/ha dose). This inorganic fertilizer is applied by making the planting hole with a distance of $\pm 5 \mathrm{~cm}$ in addition to the seeds. Inorganic fertilizer (KCL and SP36) is done at 14 DAPs, for urea fertilization was carried out 2 times at 14 DAPs and 30 DAPs, while dolomite was given before planting by sowing.

\subsubsection{Organic fertilizer}

Organic fertilizers used were Trichocompost FLBP (4000 kg-1ha dose), biourine (100 kg $\mathrm{kg}^{-1}$ ha dose). Trichocompost was applied through a mixture of cow's feces that had accumulated for 2 weeks and then coated with a mixture of sawdust, rice husk, banana stem waste, rice bran with the addition of Trichoderma $S p$ bioactivator isolated in the laboratory of the food crop protection agency (BPTP) in Jambi Province. Trichocompost FLBP was applied by sprinkling on each seed. The application was done at the beginning of planting while biourine was given twice a week by watering around the plant.

\subsection{Research design}

This study used a randomized block design (RBD), with 7 treatment groups with 5 replications, each group consisted of two experimental units. The treatments based on organic fertilizer, organic fertilizer, and biourine could be seen in Table 1 .

Table 1. Treatment Based on Combination of Inorganic, Organic, and Biourine Fertilizer

\begin{tabular}{|c|c|c|c|}
\hline \multirow[b]{2}{*}{ Treatment } & \multicolumn{3}{|c|}{$\begin{array}{c}\text { Composition of Inorganic, Organic dan } \\
\text { Biourine }\end{array}$} \\
\hline & $\begin{array}{l}\left.\text { Inorganic }{ }^{*}\right) \\
\text { N-P-K }\end{array}$ & $\begin{array}{l}\text { Organic }^{* *)} \\
\text { (Trichokomp } \\
\text { os FLBP) }\end{array}$ & $\begin{array}{l}\text { Biourine } \\
\left(\mathrm{L}^{-1} \mathbf{h a}\right)\end{array}$ \\
\hline $\mathrm{T}_{0}$ & 0 & 0 & 0 \\
\hline $\mathrm{T}_{1}$ & 1 & 0 & 0 \\
\hline $\mathrm{T} 2$ & $3 / 4$ & 0 & 0 \\
\hline T3 & $3 / 4$ & $1 / 2$ & 100 \\
\hline $\mathrm{T} 4$ & $3 / 4$ & 1 & 100 \\
\hline T5 & $3 / 4$ & $1 \frac{1}{2}$ & 100 \\
\hline
\end{tabular}




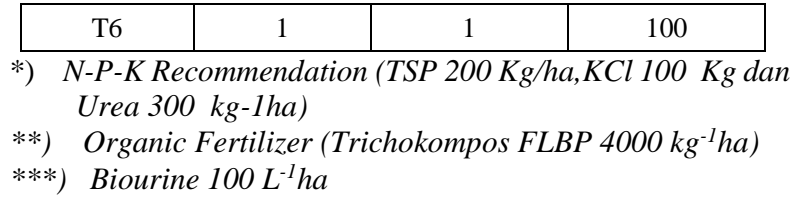

\subsection{Variables Observed}

Variable being observed consisted of: growth power $(\%)$, fruit weight $(\mathrm{g})$, sweet corn production (ton $\mathrm{ha}^{-1}$ ), and sweet corn waste production (ton $\mathrm{ha}^{-1}$ ).

\subsection{Data Analysis}

The data obtained were analyzed by Analysis of Variance (ANOVA), if there is a difference between treatments then further test required using Duncan's test. Data processing used was the SAS 9.2 program [5]

\section{RESULT AND DISCUSSION}

To see the impact of giving modified beef cattle feces and urine as a source of organic fertilizer as Trichokompos FLBP and Biourine applied to sweet corn plantations (Zea mays L.Sacc) with various fertilization combinations between inorganic, organic and biourine fertilizers can be seen from the power growth (\%), the sweet corn cobs weight $(\mathrm{g})$, sweet corn crop production (ton ${ }^{-1}$ ha), sweet corn crop waste (ton ${ }^{-1}$ ha).

\subsection{Growth Power of Sweet Corn (\%)}

The application of various combinations of organic fertilizers (Trichokompos FLBP) and Biourine and organic fertilizers will be seen from the capacity of the grown seeds. The growth ability of Sweet Corn (Zea mays L. Sacc) seeds from the application of various combinations of inorganic, organic modified feces and beef cattle urine are presented in Graph 1.

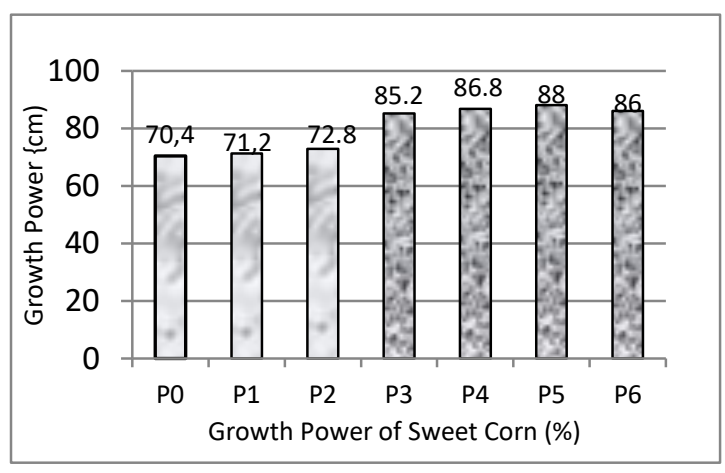

Graph1 Growth Power of Sweet Corn (Zea mays L.Sacc). Which Is Applied in Various Combinations of Inorganic and Organic Fertilizers Modified Feces and Beef Cattle Urine

The analysis showed that the growing power of sweet corn seeds from the application of inorganic fertilizers
(P1, P2, and $\mathrm{P} 3)$ was lower $(\mathrm{P}<0.05)$ compared to treatments (P3, P4, P5, and P6) that used a combination of inorganic fertilizers, organic fertilizers, and biourine. This means that the use of Trichokompos FLBP and Biourine fertilizers modified by beef cattle feces and urine can increase the growth power of sweet corn seeds. The use of a combination $\left(3 / 4 \mathrm{~N}-\mathrm{P}-\mathrm{K}+1 \frac{1}{2}\right.$ Trichokompos $F L B P+$ Biourine) in sweet corn fields increased the growth power by $88.0 \%$. Organic fertilizers, both solid and liquid, are used to supply organic matter, which can improve soil's physical, chemical, and biological properties. The application of organic fertilizers can improve soil structure, increase soil absorption material for water, improve living conditions in the soil, and as a source of nutrients for plants [1].

\subsection{Sweet Corn's Cob Weight}

Indicators to see the effect of the application of a combination of inorganic and organic fertilizer modified feces and beef cattle urine can be seen from the weight of the resulting sweet corn cobs (Zea mays L. Sacc.). The weight of sweet corn cobs (Zea mays L. Sacc) observed was the weight of sweet corn cobs (Zea mays L. Sacc) with corn husks. The weights of sweet corn with husks of each application treatment are presented in Graphs 2 and 3.

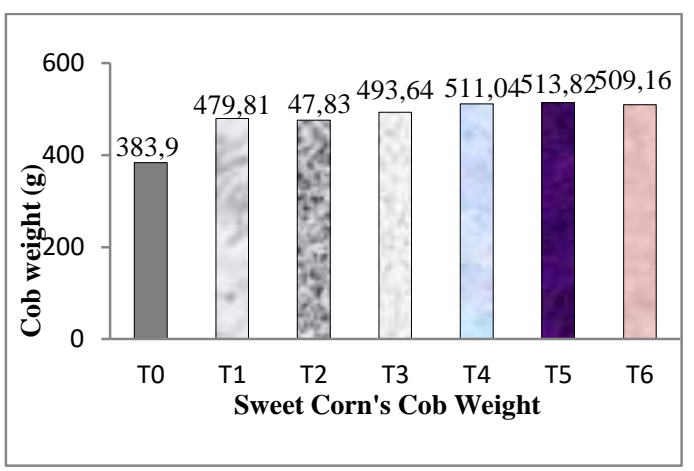

Graph 2. Weight of Sweet Corn Cobs Weighted From Application Various Combinations Of Inorganic And Organic Fertilizers Result of Modification of Beef Stool and Urine

The weight of sweet corn cobs (Zea mays saccharata sturt) resulted from the application of a combination of inorganic and organic fertilizers modified by feces and beef cattle urine (Trichokompos FLBP and Biourin) showed that the combined application at P5 ( $3 / 4 \mathrm{NPK}+$ $1 \frac{1}{2}$ Trichokompos FLBP + Biourin) resulted in the weight of sweet corn cobs was higher, namely, $511.04 \pm$ $10.88 \mathrm{~g}$ compared to the treatment $(\mathrm{P} 0, \mathrm{P} 2)$ with each ear weight $383.90 \pm 8.51$ and $479.81 \pm 17.49(\mathrm{P}<0.05)$, but relatively the same as ear weight. sweet corn globally from $\mathrm{P} 1, \mathrm{P} 3, \mathrm{P} 4$, and $\mathrm{P} 6$. Overall, the results show that the application of Trichocompost FLBP and Biourin combined with organic fertilizers can increase the weight of sweet corn cobs. The application of inorganic 
fertilizers with organic fertilizer Trichokompos FLBP and Biourine gave the same results as sweet corn (Zea mays L. Sacc) which was given the recommended fertilizer P1 (1 N-P-K). If the maize plant does not get the maximum fertilizer as in $\mathrm{P} 0$ and $\mathrm{P} 2$ (Non-Fertilizer and $3 / 4 \mathrm{~N}-\mathrm{P}-\mathrm{K}$ ), the weight of the sweet corn cobs produced is smaller than the sweet corn obtained a combination of inorganic fertilizers and organic fertilizers modified by beef cattle feces and urine. The weight gain of sweet corn cobs globally from the results of this study exceeds the weight of this variety, where the ear weight of the ear of this variety ranges from $467 \mathrm{~g}$ until $497 \mathrm{~g}$ [6] The results of this study are much higher than the results of research [4] who obtained the weight of sweet corn cobs was only 306.66 grams from the combined application of Trichocompost Rice Straw + EFB + Tofu Dregs. With the high weight of sweet corn cobs globally in this study, it is possible that the nutrients are complementary. The results of the Trichokompos FLBP chemical test have met the standards of PERMENTAN 01/2019 for the requirements for organic fertilizers. for organic COrganik 29.15\%, C/N 28, macronutrients ( + P2O5 + $\mathrm{K} 2 \mathrm{O}) 4.54 \%$, pH 8, and microelements ( $\mathrm{Fe}, \mathrm{Fe}$ available, $\mathrm{Zn}$ Total, Mn Total, $\mathrm{Cu}$ Total) have met the standard of Permentan 01/2019. Nutrients from Trichokompos FLBP with a combination of inorganic fertilizers and biourine, especially $\mathrm{P}$ and $\mathrm{K}$ elements, play a role in ear cob formation. In particular, $P$ elements that affect the development of ear and seed size and $\mathrm{K}$ which plays a role in accelerating the allocation of nutrients in increasing the quality of the cob for the better. Furthermore, it was argued that the $\mathrm{P}$ element can increase the high production of plants, improve yields and accelerate the ripening period of seeds and fruits [7]

\subsection{Sweet Corn (Zea mays saccharata sturt) Production}

The production of sweet corn per ha is closely related to the weight of sweet corn with a weight. The production of sweet corn globally from each fertilization application is presented in Graph 3.

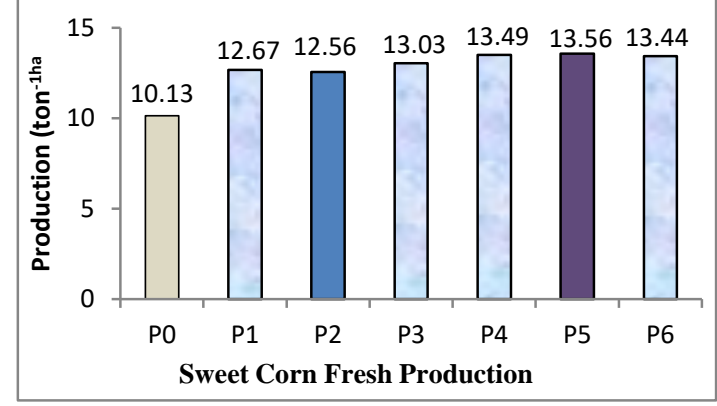

Graph 3. Production of Sweet Corn (Zea mays saccharata sturt) From Application Various
Combinations Of Inorganic And Organic Fertilizers Modified Beef Stool and Urine Results

From Graph 3, it can be seen that the highest sweet corn production was obtained in the P5 application, namely the application $\left(3 / 4 \mathrm{NPK}+1 \frac{1}{2}\right.$ Trichokompos FLBP + Biourin) with the production per hectare obtained by 13.56 tons. Compared with P0, P1, P2, and P3 (10.03 tonnes -1 ha, 12.67ha-1, and 12.56 ton-1ha) (P $<0.05$ ), while those with P4 and P6 were relatively the same. This result is closely related to the weight of sweet corn cobs produced. Based on Graph 2. In the P0 treatment, the weight of corn cob was lower, while the highest weight of corn husk was at P5. The heavier the cobs of sweet corn are globular, the higher the production of sweet corn will be. [8] stated that the weight of the cobs of sweet corn plants will affect the sweet corn yield. The combination of organic and organic fertilizer significantly increased maize yield [9]

\subsection{Sweet Corn Waste Production}

Sweet corn waste in the form of stems, leaves, flowers is waste that can be used as animal feed. The production of sweet corn waste from the application of various combinations of inorganic, organic, and biourine fertilizers is presented in graphs 4 .

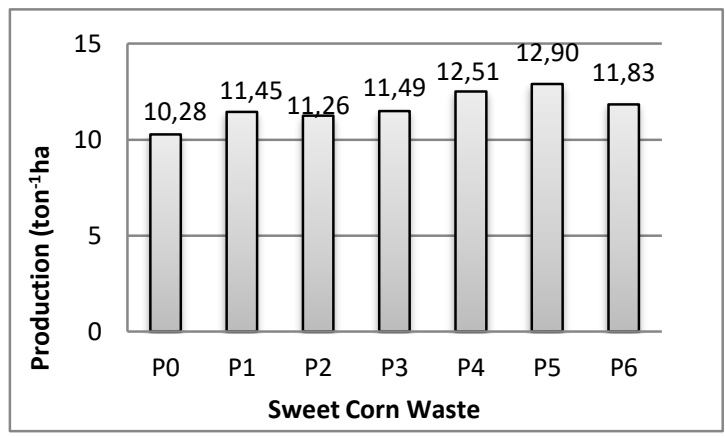

Graph 4. Waste Production of Sweet Corn (Zea mays saccharata sturt) From Applications Of Various Combinations and Inorganic Fertilizers Organic Modified Beef Stool and Urine

The analysis showed that the highest waste of sweet corn was produced from $\mathrm{P} 5$, then $\mathrm{P} 4$, and $\mathrm{P} 6$, while $\mathrm{P} 1$, $\mathrm{P} 2$, and $\mathrm{P} 3$ and $\mathrm{P} 4$ were relatively the same. The lowest production of sweet corn waste was obtained at $\mathrm{P} 0$, namely 10.28 tonnes $^{-1}$ ha. The highest waste of sweet corn was produced from the application of P5 which reached 12.90 tonnes $^{-1}$ ha. The higher the production of plants produced, the higher the production of plant waste produced [10]. The availability of sweet corn waste has the potential to be used as a source of ruminant livestock, especially beef cattle. Food crop waste has great potential as a source of ruminant feed. Utilization of this waste can reduce environmental damage because farmers usually leave their waste untapped. From the availability of this waste, it can be calculated "Carrying Capacity of Plant Waste" as beef cattle feed, by calculating the total waste 
production (dry matter) from the harvested area (ha) $\mathrm{x}$ fresh waste production (tonha ${ }^{-1}$ ) $\mathrm{x}$ dry matter content of the waste $(\%)$ and divided by the dry matter requirement (BK) of beef [11] waste of 12.90 tonnes-1ha. Based on this calculation, the available sweet corn waste potential can accommodate 4 UT of beef cattle

\section{CONCLUSION}

Application of organic fertilizers through modification of feces and beef cattle urine into Trichokompost and biourine combined with inorganic fertilizers can increase growth power, cob weight globally, sweet corn production, and sweet corn waste production (Zea mays saccharata sturt)

Growth capacity, the weight of sweet corn cobs (Zea mays saccharata sturt), production of sweet corn, and production of waste of sweet corn (Zea mays L. Sacc) were obtained from the application of a combination of inorganic, organic, and biourine fertilizers with the pattern $(3 / 4$ NPK + 11/2 Trichokompos FLBP + biourine)

Sweet corn waste (Zea mays saccarata sturt.) Has the potential to be used as feed for beef cattle.

\section{AUTHORS' CONTRIBUTIONS}

The title "AUTHORS' CONTRIBUTIONS" should be in all caps.

\section{ACKNOWLEDGMENTS}

Thank you to the Rector of Jambi University who has provided research funds for the Accelerated Professor Research scheme

\section{REFERENCES}

[1] F. Dewanto, G.Londok, J.M.R. Tuturoong, R.A.V, Kaunang, The effect of inorganic fertilization on the production of maize as a source of animal feed in : JournalZootek,32(5).1-8.

DOI : https://doi.org/10.35792/zot.3

[2] Sudana, M., G.N.A.S Wirya, P.Sudiarta. Utilization of Biourin as Biopesticide and Organic Liquid Fertilizer in Green Mustard Cultivation (Brassica rapa var. Parachnensis). Organic. Research Report Year 1 (2012). Denpasar: Udayana University

[3] Zein. Organic Liquid Fertilizer (PCO). In: https://www.kampoengternak.or.id2011. Retrieved 6 May 2016.

[4] I.A Setiawan' Utilizing Animal Manure in: Penebar Swadaya. Jakarta.2007.

[5] SAS. User Guide 9.0 in: SAS Institute, Cary,North Carlona, America Serikat.2010
[6] A, Priyantono, Attachment to the decree of the minister of agriculture in Number 2071/Kpts/SR.120/5/2009, Date May 17, 2009. https://varietas.net/va ritas10/varimage/jagungmanisbonanza.pdf.

[7] R.Hartati, H.yetti, F. Puspita, Giving Trichocompost Some Organic Ingredients On The Growth And Production Of Sweet Corn (Zea Mays SaccharataSturt) in : R.Ita Hutasoit, N.Setyowati, M.Chozin, JIPI 22 (1),2020 pp 45-51

DOI :https://doi.org/10.31186/jipi.22.1.45-51

[8] S,Musahnati and Rahayu, The Effect of Tithonia Compost Measures on Growth and Yield of Sweet Corn (Zea mays) in : J. Jerami (1)(2) 2006 pp: 87 91. URI:http://repository.unand.ac.id/id/eprint/2532

[9] A,Mukuralinda, JS Tenywal, L. Vercot,J. Obua,NL Nabahungu and JN Chianu, Phosphorus uptake and maize response to oraganic and in organic fertilizer inputs in Rubona, Southern Province of Rwanda. In : Agroforest Syst 2010 pp: 211-221 DOI: https://doi.org/10.1007/s10457-010-9324-9

[10] S.A.A, Tani, B.P.Purwanto, M.Ghulamahdi, A.Fuah,Salundik,W,A,Ridwan, Integration of Beef Cattle and Soybean on Tidal Swamp. Pakistan Journal Of Nutrition (16) 2017 : 193-199. DOI: $10.3923 /$ pjn.2017.193.199

[11] J.A. Syamsu, Analysis of the Potential of Plant Waste as a Source of Ruminant Animal Feed in South Sulawesi. [Dissertation]. Postgraduate Bogor Agricultural Institute. Bogor-Indonesia 2006. 